\title{
FAKTOR-FAKTOR YANG BERPENGARUH TERHADAP TINGKAT KEMANDIRIAN PETANI KEDELAI DI KECAMATAN PANCATENGAH KABUPATEN TASIKMALAYA
}

\author{
FACTORS AFFECTING THE LEVEL OF INDEPENDENCE OF SOYBEAN \\ FARMERS IN PANCATENGAH SUBDISTRICT, TASIKMALAYA DISTRICT
}

\author{
Dedi Djuliansah*, Trisna Insan Noor, Yosini Deliana, Meddy Rachmadi \\ Fakultas Pertanian, Universitas Padjadjaran \\ "Email: ddjuliansah@gmail.com \\ (Diterima 20-07-2020; Disetujui 28-07-2020)
}

\begin{abstract}
ABSTRAK
Permintaan kedelai yang meningkat setiap tahunnya tidak diimbangi dengan laju peningkatan produksi dalam negeri yang signifikan meski berbagai program pemerintah telah digulirkan. Hal tersebut membuat ketergantungan pada kedelai impor begitu tinggi. Upaya melalui pemberdayaan petani untuk membuat petani berdaya dan memiliki kemandirian dalam usahatani kedelai menjadi sebuah urgensi. Penelitian ini bertujuan untuk mengetahui tingkat kemandirian petani kedelai dan menganalisis faktor-faktor apa saja yang mempengaruhi tingkat kemandirian petani. Penelitian dilaksanakan dengan menggunakan metode survei di Kecamatan Pancatengah, Kabupaten Tasikmalaya yang merupakan daerah pengembangan kedelai potensial di Jawa Barat dengan mengambil sampel sebanyak 84 petani kedelai menggunakan simple random sampling. Data yang dikumpulkan dalam penelitian ini terdiri atas data sekunder dan data primer. Metode analisis data yang akan digunakan dalam penelitian ini menggunakan analisis deskriptif dan analisis regresi linier berganda. Hasil penelitian menunjukan bahwa (1) tingkat kemandirian petani kedelai di Kecamatan Pancatengah termasuk kategori sedang (28,57\%), motivasi sedang (32,14\%), kemampuan tinggi $(33,33 \%)$, kedinamisan rendah $(34,52 \%)$, keberdayaan sedang $(50 \%)$, lingkungan sosial budaya tinggi $(33,33 \%)$, kinerja penyuluhan sedang $(39,29 \%)$ dan partisipasi tinggi $(40,48 \%)$, (2) motivasi, kemampuan, keberdayaan, dan partisipasi berpengaruh signifikan terhadap kemandirian petani kedelai, sedangkan kedinamisan, lingkungan sosial budaya dan kinerja penyuluhan tidak berpengaruh signifikan.
\end{abstract}

Kata kunci: petani, kedelai, kemandirian, faktor-faktor

\section{ABSTRACT}

Soybean demand that increases every year is not offset by a significant increase in domestic production despite various government programs. This makes the dependence on imported soybeans so high. Efforts through empowering farmers to make farmers empowered and independent in soy farming are an urgency. This study aims to determine the level of independence of soybean farmers and analyze what factors influence the level of independence of farmers. The study was conducted using a survey method in Pancatengah, Tasikmalaya District which is a potential soybean development area in West Java by taking a sample of 84 soybean farmers using simple random sampling. Data collected in this study consisted of secondary data and primary data. Data analysis method that will be used in this study uses descriptive analysis and multiple linear regression analysis. The results showed that (1) the level of independence of soybean farmers in Pancatengah District was included in the moderate category (28.57\%), moderate motivation (32.14\%), high ability (33.33\%), low dynamism (34.52\%), moderate empowerment $(50 \%)$, high social cultural environment (33.33\%), moderate counseling performance (39.29\%) and high participation (40.48\%), (2) Motivation, ability, empowerment, and participation significant effect on the independence of soybean farmers, while dynamics, socio-cultural environment and extension performance did not have a significant effect. 
Keywords: farmers, soybeans, independence, factors

\section{PENDAHULUAN}

Kedelai merupakan tanaman penting untuk pemenuhan kebutuhan pangan dalam rangka perbaikan gizi masyarakat, sebagai sumber protein nabati yang relatif murah bila dibandingkan sumber protein lainnya seperti daging, susu, dan ikan. Kadar protein biji kedelai lebih kurang 35\%, karbohidrat 35\%, dan lemak 15\%. Selain itu, kedelai juga mengandung mineral seperti kalsium, fosfor, besi, vitamin A dan B (Hilman dkk, 2004).

Permintaan kedelai yang meningkat setiap tahunnya tidak diimbangi dengan laju peningkatan produksi dalam negeri yang signifikan meski berbagai program pemerintah telah digulirkan. Hal tersebut sejalan dengan yang dikemukakan Nainggolan dkk (2016) bahwa sampai saat ini masih terjadi kesenjangan antara jumlah produksi dengan konsumsi kedelai dalam negeri, sehingga seringkali dipenuhi dengan kedelai impor. Meski adanya kenaikan produksi kedelai dalam negeri beberapa tahun terakhir, hal tersebut belum dapat mengimbangi laju konsumsi kedelai seiring perkembangan jumlah penduduk.

Salah satu upaya yang saat ini dilakukan adalah melalui penyuluhan pertanian dan pendampingan petani sebagai bentuk pemberdayaan petani kedelai, dengan harapan petani mampu dan mandiri melaksanakan usahatani kedelai demi tercapainya swasembada. Penelitian ini bertujuan untuk mengetahui tingkat kemandirian petani kedelai dan menganalisis faktor-faktor apa saja yang mempengaruhi tingkat kemandirian petani.

\section{METODE PENELITIAN}

Penelitian dilaksanakan dengan menggunakan metode survei di Kecamatan Pancatengah, Kabupaten Tasikmalaya yang merupakan daerah pengembangan kedelai potensial di Jawa Barat dengan mengambil sampel sebanyak 84 petani kedelai menggunakan simple random sampling.

Data yang dikumpulkan dalam penelitian ini terdiri atas data primer dan data sekunder. Data primer merupakan data yang diperoleh langsung dari petani kedelai dengan teknik wawancara (interview) dengan panduan kuesioner. Sedangkan data sekunder dari dinas dan intansi terkait, jurnal, buku dan sumber data lainnya.

Variabel yang diteliti dalam penelitian ini adalah kemandirian petani 
(Y), motivasi (X1), kemampuan petani (X2), kedinamisan petani (X3), keberdayaan petani (X4), lingkungan sosial budaya (X5), kinerja penyuluhan (X6), dan partisipasi (X7), diukur melalui item pertanyaan dengan 5 poin Skala Likert. Metode analisis data yang digunakan dalam penelitian ini menggunakan analisis deskriptif dan analisis regresi linier berganda.

\section{HASIL DAN PEMBAHASAN}

\section{Tingkat Kemandirian Petani Kedelai}

Petani dalam melaksanakan kegiatan usahataninya saat ini dituntut tidak hanya berorientasi pada produk yang dibutuhkan pasar, tetapi harus mampu menciptakan pasar dan bersaing dengan produk pertanian negara lain terkait mutu, produktivitas dan efisiensi.

Menyikapi kondisi demikian, Effendi (2012) menyebutkan bahwa para petani diharapkan mampu mandiri dan tangguh dalam melaksanakan usahatani, dan tidak lagi mengharapkan subsidi dan proteksi dari pemerintah. Kemandirian petani untuk mewujudkan ketangguhan berusahatani adalah suatu kondisi yang dapat ditumbuhkan melalui proses pemberdayaan (empowerment).

Pemberdayaan ke arah kemandirian petani dapat diwujudkan salah satunya melalui kegiatan penyuluhan. Petani perlu dilibatkan secara aktif dalam proses belajar agar mampu mengetahui masalah yang dihadapi dan menentukan sendiri berbagai alternatif pilihan untuk mengatasinya.

Hasil penelitian menunjukan bahwa tingkat kemandirian petani kedelai di Kecamatan Pancatengah termasuk kategori sedang (28,57\%) (Gambar 1). Artinya petani kedelai di Kecamatan Pancatengah masih belum bisa menjalankan usahatani kedelai secara mandiri tanpa bantuan pemerintah. Hal tersebut tentunya disebabkan beberapa alasan petani yang sebagian besar menyatakan tidak adanya jaminan pembelian dan jaminan harga serta ketakutan terhadap gagal panen. Sebagai dampak dari ketidakmampuan mereka dalam mengatasi serangan hama dan penyakit tanaman kedelai. 


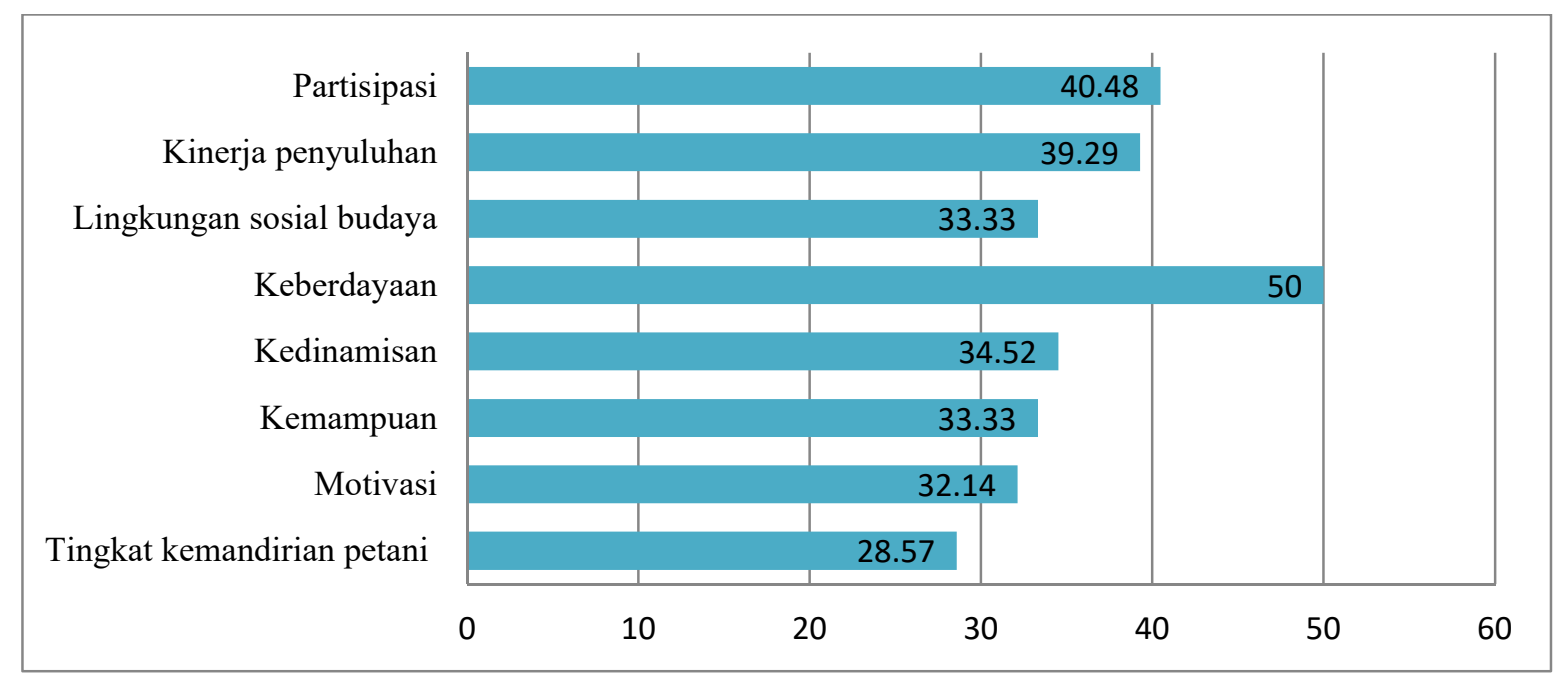

Gambar 1. Persentase Jawaban Resonden

\section{Motivasi Petani Kedelai}

Motivasi adalah suatu dorongan atau tekanan yang menyebabkan seseorang untuk melakukan sesuatu kegiatan (Mardikanto, 1987). Motivasi juga dapat diartikan sebagai "dorongan" dari dalam diri setiap individu ataupun "tarikan" dari eksternal sebagai kekuatan yang potensial untuk melakukan suatu kegiatan.

Motivasi petani kedelai di Kecamatan Pancatengah termasuk kategori sedang (32,14\%) (Gambar 1). Masih terdapatnya sebagian petani yang ragu untuk melaksanakan usahatani kedelai dikarenakan tidak adanya jaminan harga dan jaminan pembelian membuat kurang bergairah untuk menanam kedelai. Meski tidak sedikit petani yang optimis melaksanakan usahatani kedelai dengan input seadanya (minimal input) dan dengan menggunakan teknologi sederhana, seperti tidak melakukan olah tanah. Hal tersebut sejalan dengan yang dikemukakan Mardiharini dkk (1990) bahwa motivasi petani kedelai masih belum tinggi yang dikarenakan beberapa hal, diantaranya produktifitas rendah, rentan serangan hama penyakit, dan teknologi yang digunakan masih tradisional atau sederhana.

\section{Kemampuan Petani Kedelai}

Kemampuan petani kedelai di Kecamatan Pancategah termasuk kategori tinggi (33,33\%) (Gambar 1), artinya kemampuan atau kapasitas petani kedelai dalam melaksanakan usahatani kedelai sudah baik. Memang sudah sejak lama dan turun temurun orang tua para petani di Kecamatan Pancatengah telah 
melaksanakan usahatani kedelai meski dengan teknologi sederhana atau tradisional. Sehingga sampai saat ini masih banyak petani yang melaksanakan usahatani kedelai di Kecamatan Pancatengah.

Hal yang menarik adalah pada saat petani mendapatkan fasilitas bantuan sarana produksi dan pendampingan usahatani kedelai oleh penyuluh pertanian, masih banyak petani yang tidak mengikuti anjuran dan malah memilih untuk menerapkan teknologi sederhana yang seringkali diterapkan oleh orang tua zaman dahulu.

\section{Kedinamisan Petani Kedelai}

Kedinamisan petani dapat dilihat dari keinginan yang sungguh-sungguh pada individu petani untuk percaya pada dirinya sendiri dan tidak tergantung pada pihak lain. Hasil penelitian menunjukkan bahwa kedinamisan petani kedelai di Kecamata Pancatengah termasuk kategori rendah $(34,52 \%)$ (Gambar 1), hal tersebut karena petani kurang optimal dalam menjalankan usahatani kedelai yang hanya menerapkan minimal input.

Artinya petani kedelai kurang ataupun masih lemah dalam menerima dan mengadopsi inovasi-inovasi baru terkait teknologi budidaya kedelai. Hal tersebut tentunya bertentangan dengan definisi petani dinamis yang dikemukakan Pertiwi dan Setijorini (2006) bahwa petani yang dinamis adalah yang memiliki ciri-ciri kedinamisan, yaitu: prestatif, mau bekerja keras, luwes bergaul, mandiri dan inovatif.

\section{Keberdayaan Petani Kedelai}

Keberdayaan petani kedelai di Kecamatan Pancategah termasuk kategori sedang (50\%) (Gambar 1), hasil ini tentunya berkaitan dengan rendahnya kedinamisan petani. Karena prinsipprinsip dalam mengukur keberdayaan masyarakat (petani) membutuhkan facilitating factors, yakni kelompok masyarakat yang dinamis (group dynamics) dan pendamping/fasilitator yang kompeten.

Hal lain yang mendukung hasil penelitian ini juga kemampuan petani dalam menerapkan teknologi sederhana yang turun temurun. Kelebihannya adalah petani kedelai menggunakan rasionalitasnya sendiri dalam pengambilan setiap keputusan dengan pertimbangan-pertimbangan seperti pengalaman usahatani, penentuan waktu tanam dan waktu panen dan masih banyak lainnya. 


\section{Lingkungan Sosial Budaya}

Hasil penelitian menunjukkan lingkungan sosial budaya termasuk kategori tinggi (33,33\%) (Gambar 1), artinya lingkungan sosial budaya di Kecamatan Pancatengah sangat mendukung pengembangan usahatani kedelai.

Sehingga dengan demikian pengembangan usahatani kedelai dapat berkelanjutan dengan adanya dukungan lingkungan sosial budaya yang baik. Selain itu adanya daya dukung lingkungan sosial budaya yang tinggi pula secara otomatis partisipasi masyarakat (petani) dalam mensukseskan pengembangan kedelai akan meningkat atau tinggi.

\section{Kinerja Penyuluhan}

Tujuan utama dari penyuluhan pertanian adalah membantu dan memfasilitasi agar mampu mengubah perilaku petani dan keluarganya sehingga dapat mengelola usahataninya dengan produktif, efektif dan efisien. Sehingga kinerja penyuluhan di sini diartikan sebagai tingkat ketercapaian penyuluh pertanian dalam memfasilitasi petani kedelai untuk menjalankan usahataninya sampai petani mampu mengadopsi teknologi dan menyerap informasi dari penyuluh pertanian.

Hasil penelitian menunjukkan kinerja penyuluhan termasuk kategori sedang (39,29\%) (Gambar 1), artinya peran penyuluh pertanian belum optimal karena masih terdapat sebagian petani yang masih tidak mengikuti anjuran dalam melaksanakan usahatani kedelai. Selain itu keterbatasan penyuluh pertanian dalam memberikan informasi penanganan hama dan penyakit tanaman kedelai.

\section{Partisipasi}

Hasil penelitian menunjukkan partisipasi petani dalam melaksanakan usahatani kedelai termasuk kategori tinggi (40,48\%) (Gambar 1), artinya sebagian besar petani ikut berperan serta dalam mensukseskan pengembangan kedelai di Kecamatan Pancatengah.

Secara sukarela petani di Kecamatan Pancatengah menanam kedelai, ada yang memang sudah sejak dahulu menanam kedelai dan ada juga yang hanya mencoba karena mendapatkan bantuan sarana produksi untuk usahatani kedelai. Semakin tinggi partisipasi petani dalam menjalankan usahatani kedelai maka akan terbangun modal sosial yang kuat pula dalam 
percepatan pengembangan kedelai di Kecamatan Pancatengah.

\section{Faktor-faktor yang Berpengaruh} Terhadap Tingkat Kemandirian Petani

\section{Kedelai}

Berdasarkan hasil pengolahan data dan perhitungan (Tabel 1) diperoleh kesimpulan bahwa motivasi (X1), kemampuan (X2), keberdayaan (X4), dan partisipasi (X7) berpengaruh signifikan terhadap kemandirian petani kedelai $(\mathrm{Y})$ dapat dilihat dari nilai Sig. masingmasing variabel $\mathrm{p}<0,005$, sedangkan kedinamisan (X3), lingkungan sosial budaya (X5), dan kinerja penyuluhan (X6) tidak berpengaruh signifikan dapat dilihat dari nilai Sig. masing-masing variabel $p>0,005$.

Tabel 1. Hasil Output Analisis Regresi Linier Berganda

\begin{tabular}{|c|c|c|c|c|c|c|}
\hline & \multirow[t]{2}{*}{ Model } & \multicolumn{2}{|c|}{ Unstandardized Coefficients } & $\begin{array}{c}\text { Standardized } \\
\text { Coefficients }\end{array}$ & \multirow[t]{2}{*}{$\mathrm{t}$} & \multirow[t]{2}{*}{ Sig. } \\
\hline & & $\mathrm{B}$ & Std. Error & Beta & & \\
\hline \multirow[t]{8}{*}{1} & (Constant) & $-2,843$ & ,414 & & $-6,865$ &, 000 \\
\hline & $\mathrm{X} 1$ & ,440 &, 056 & ,429 & 7,929 &, 000 \\
\hline & $\mathrm{X} 2$ & ,394 & ,049 &, 425 & 8,106 &, 000 \\
\hline & $\mathrm{X} 3$ & ,059 & ,060 &, 053 & ,986 & ,327 \\
\hline & $\mathrm{X} 4$ & ,430 &, 059 &, 387 & 7,299 &, 000 \\
\hline & $\mathrm{X} 5$ & ,107 &, 042 &, 134 & 2,520 &, 014 \\
\hline & X6 & ,023 & ,064 &, 019 &, 357 &, 722 \\
\hline & $\mathrm{X} 7$ &, 425 &, 048 & ,484 & 8,804 &, 000 \\
\hline $\begin{array}{l}\text { F hitung } \\
\text { R Square }\end{array}$ & $\begin{array}{r}42,166 \\
0,795\end{array}$ & & & & & \\
\hline
\end{tabular}

a. Dependent Variable: Y

Tingginya kemampuan petani dan partisipasinya dalam usahatani kedelai sangat berpotensi untuk mendukung keberlanjutan pengembangan kedelai di Kecamatan Pancatengah. Selain itu, dengan adanya motivasi dan keberdayaan petani kedelai di Kecamatan Pancatengah akan terbangun pula modal sosial yang kuat dalam mendukung keberlanjutan pengembangan kedelai.

Kedinamisan petani yang cenderung rendah diakibatkan daya adopsi inovasi teknologi petani yang rendah pula kurang mendukung untuk kemandirian petani kedelai. Selain itu, kinerja penyuluhan pun termasuk kategori sedang yang disebabkan masih 
lemahnya kinerja penyuluhan dan pendampingan petani dalam melaksanakan usahatani kedelai. Meskipun dukungan lingkungan sosial budaya yang tinggi di Kecamatan Pancatengah, namun hal tersebut tidak menjadi jaminan petani kedelai secara otomatis menjadi mandiri, hal tersebut kembali lagi ke setiap individu petani yang memiliki semangat, motivasi, optimisme, dan inovatif dalam menjalankan usahatani kedelai.

\section{KESIMPULAN DAN SARAN}

Hasil penelitian menunjukan bahwa (1) tingkat kemandirian petani kedelai di Kecamatan Pancatengah termasuk kategori sedang (28,57\%), motivasi sedang $(32,14 \%)$, kemampuan tinggi $(33,33 \%)$, kedinamisan rendah $(34,52 \%)$, keberdayaan sedang $\quad(50,00 \%)$, lingkungan sosial budaya tinggi $(33,33 \%)$, kinerja penyuluhan sedang (39,29\%) dan partisipasi tinggi (40,48\%), (2) Motivasi, kemampuan, keberdayaan, dan partisipasi berpengaruh signifikan terhadap kemandirian petani kedelai, sedangkan kedinamisan, lingkungan sosial budaya dan kinerja penyuluhan tidak berpengaruh signifikan.

\section{DAFTAR PUSTAKA}

Effendi, M. (2012). Peranan Kelompok Tani dalam Mengembangkan Kemandirian Petani di Kabupaten Tana Tidung. Jurnal Program Studi Agribisnis Fakultas Pertanian Universitas Mulawarman 35(3): 204-216.

Hilman. Y. A, Kasno, dan N. Saleh. (2004). Kacang-kacangan dan umbi-umbian: Kontribusi terhadap ketahanan pangan dan perkembangan teknologinya. dalam Makarim, et al. (penyuting). Inovasi pertanian tanaman pangan. Puslitbangtan Bogor: 95-132 hlm.

Mardiharini, M. Muchlas NFN. M. Taufik, dan Tahlim Sudaryanto. (1990). Studi Diagnostik Pengembangan Usahatani Kedelai di Desa Karyamukti, Kabupaten Karawang. Jurnal Agro Ekonomi, 9(1):57-82.

Mardikanto. (1987). Komunikasi Pembangunan. Sebelas Maret University Press Surakarta.

Nainggolan, K. U. I Dewa Gede Agung, I Made Narka Tenaya. (2016). Pengaruh Produksi, Konsumsi, dan Harga Kedelai Nasional terhadap Impor Kedelai di Indonesia Periode 1980 Sampai dengan 2013. EJurnal Agribisnis dan Agrowisata, 5(4): 742-751.

Pertiwi, P.R., Setijorini, L.E. dan Harijati, S. (2006). Dinamika Petani Perkotaan. Jurnal Penyuluhan Pertanian 2(1): 134-146. 